\title{
An Analysis of Risk-Taking in Family Firms Listed in B3
}

\author{
Gabriel Voelcker ${ }^{1}$ \\ gvoelcker@gmail.com | @0000-0003-4815-3658 \\ Clea Beatriz Macagnan ${ }^{1}$ \\ clea@unisinos.br | @0000-0002-9097-7266 \\ Daniel Vancin ${ }^{1}$ \\ daniel_vancin@hotmail.com | (10)0000-0001-6303-0555
}

\begin{abstract}
This work analyses the statistical relationship between family firms and risk-taking. It seeks to contribute to the growing literature on family firms by reviewing the literature on the characteristics that distinguish them from non-family firms, aiming to innovate by approaching a less-used construct for this type of firm: risk-taking. The literature on both constructs is reviewed, using theoretical and empirical works to develop the following research hypothesis: tfamily firms are more averse to risk-taking than non-family firms. This hypothesis is tested empirically using econometrics procedures in a sample with 1188 observations from publicly traded companies listed on B3. The results indicate that the presence of family firms negatively affect risk-taking. Thus, it can be concluded that family firms seem to be less prone to risk-taking than non-family firms.
\end{abstract}

\section{KEYWORDS}

Family firms, Risk-taking, Decision-making 


\section{INTRODUCTION}

In Brazil, family firms represent more than $90 \%$ of the total market (Laruccia \& Matias, 2015), indicating the economic and social relevance of this organization profile and the role it plays in the country's financial system (Moura et al., 2015). For this reason, recent research has given more attention to organizations classified as family members and the motivations of business families (Borges et al., 2010; Belmonte; Freitas, 2013; Tres et al., 2014; Costa et al., 2014).

When the controlling shareholder or shareholders of a firm is a family or members of a family, it enables the business family to actively participate in the decisions made for it (de Vries, 1993). Ownership and involvement in the company's operations influence decisions made by the firm in a particular way, leading to another dynamic of relationships (Casillas et al., 2011; Revilla et al., 2016).

Among the most critical decisions a firm must make is risk-taking. Risk has been the object of study by economics, finance, and accounting researchers for decades, having implications in the most diverse spheres (Markowitz, 1952; Sharpe, 1964; John et al., 2008; Zyphur et al., 2009). Risk is defined for decision making as the uncertainty associated with the return that a choice provides (Fama, 1983; March \& Shapira, 1987). Risk-taking represents all risk decisions that managers make, not focusing on a specific type of risk, such as tax risk (John et al., 2008; Faccio et al., 2011).

Risk-taking studies seek to understand the incentives that decision-makers responds to and how they may vary according to a range of factors (Amihud \& Lev, 1981; Zyphur et al., 2009). In the case of firms, the manager would be influenced by their personal preferences (Fama \& Jensen, 1983). This theoretical construct was formalized in Agency Theory - see Jensen and Meckling (1976), which adresses the various repercussions of the separation between control and property. Among them are the risk preferences of managers (Eisenhardt, 1989), who differently behave if they are also firm owners (in this case, business families) and non-external professionals whose relationship is only managing the firm.

In this context, the objective of this research is to investigate whether family firms are more risk-averse than unfamiliar firms. We assume that family involvement in business decisions affects the way companies take risk. Due to the concentration of the business family equity invested in the firm, the firm chooses to prioritize the firm's long-term survival over potential entrepreneurial opportunities that comprise risk. Also contributing to risk aversion is the preservation of family socio-emotional heritage, which contains several non-economic goals (Laffranchini \& Braun, 2014).

This paper conducts empirical tests with a Brazilian sample to see if family firms are at higher risk than non-family firms. The econometric procedures seek to control several characteristics of the firm, having as a variable of interest a dummy that segregates the firms of the sample between family and non-family. The data collected comprised the period from 2010 to 2017 and were submitted to mean difference tests, regressions using Ordinary Least Squares, and an average treatment effects test, in which we paired firms by propensity score matching. The results obtained indicate that family firms take less risk than unfamiliar firms; that is, they would be more risk-averse.

The relevance of this work is to add useful knowledge to both internal and external agents. Internally, we create new evidence about the impact of family presence on risk-taking decisions, which is helpful for both the self-knowledge of family business members and the managers who deal with them. In the external impact of the firm, we add knowledge to the nearly 600,000 active investors in B3 (Brazil Bolsa Balcão S.A.), Brazil's stock exchange, who are interested in 
the profile of listed firms in which they can invest. It also differs in generating insights into the Brazilian market, which has an internationally relevant volume and trading value, while the revised literature has been devoted to analyzing markets with lower shareholder concentration and more excellent shareholder protection, such as in the US example.

We divide the research into five chapters. The present one introduces the work and its structuring. The second deals with the literature review, which works the family firm and risktaking constructs, culminating in the formulation of the hypothesis. The third chapter presents the methodology, describing in detail the empirical tests employed. The fourth presents and analyzes the results obtained by the method, while the fifth and last chapter presents the final considerations of the work.

\section{LITERATURE REVIEW}

\subsection{FAMily Firms}

One of the challenges of literature related to family firms is to determine the criteria that characterize a firm as a family one (Handler, 1989). The image of a family business is commonly associated with a small structure organization, primarily as they represent the main form of business structuring in several countries of the world, including in Brazil (Costa et al., 2014). However, research attests to the presence of business families as controlling companies of large firms (Anderson \& Reeb, 2003).

Defining what is a family business is a crucial step, and this is the first step to understand its operation (Litz, 1995). Also, a clear definition of family name allows for a better choice and standardization of the data used. For example, the statement that $90 \%$ of firms in Brazil are family-owned (Laruccia \& Matias, 2015) depends on the definition of what is a family firm. The description serves not only to elaborate on the characteristics that define the family firm but to facilitate the sampling and application of the methodology in empirical works such as the present. The reviewed literature has no consensus on requirements that, once fulfilled, configure an organization as a family business (Handler, 1989). What exists is a series of characteristics that underlie this definition, here revised to obtain the meaning to be used as a family name in this research.

The first feature addressed is the controlling interest that the family has in the firm. We expect a family with a firm's controlling capabilities to actively participate in its business to protect its interests (Anderson \& Reeb, 2003; Revilla, Pérez-Luño, \& Nieto, 2016). This involvement manifests itself when its members take senior management positions and/or serve on the firm's board of directors. This implies that family presence may allow the manifestation of the particularities of the business family in a different behavior as managers. Studying these particularities helps analyz the incentives and motivations of the family firm's functioning. Among these particularities, six stand out: the concentration of family financial equity, Family Socio-Emotional Heritage (FSH), the relationship between family members, long-term orientation, family succession, and retention of control.

The concentration of family financial equity consists of the alignment of capital between the firm and business family. Because the firm is one of the essential parts of the business family's life, given its inevitable involvement in the most diverse capacities, members of the business family tend to focus their investment position on the firm more than other managers or investors (Pukall,Calabrò). 2014). This undiversified position of the business family results in a differentiated attitude towards the decisions made (Huybrechts \& Voordeckers; Lybaert, 2013). 
BBR

17

402

The second characteristic of family firms concerning family equity is Family Socio-Emotional Heritage (FSH), a concept elaborated by (Gómez-Mejía et al., 2007) that includes the nonfinancial aspects of the firm. These meet the family's affective needs with their firm, as the former has goals that are unrelated to the firm's economic performance and may even be prioritized for the firm's growth and profitability (Cater III \& Justis, 2009).

Another factor addressed by the family firm literature is the relationship between family firm members, which influences the way strategic decisions are made in family firms (Cater; Justis, 2009). It is considered positive for the operation of the business that families facilitate communication and reduce bureaucracy in some relationships, allowing unique flexibility to their process based on relationships of trust and altruism (Miralles-Marcelo, Miralles-Quirós, \& Lisboa, 2014). In contrast, the distinct interests of each member of the business family and their long-term relationship can catalyze internal conflicts (Jayantilal, Jorge, \&Palacios, 2016). The family business is especially exposed to disagreement over the particular interests that the parties involved may have with family members or with the company and the history of their relationships.

The fourth factor that is a particularity of family firms is long-term orientation, meaning that decisions are made with the long-term horizon of family firms in mind (Pukall \& Calabrò, 2014). The primary purpose of long-term guidance is to ensure the firm's survival, as it is mostly in the business family's interest to keep the firm under its control (Martínez-Ferrero, Rodríguez-Ariza, \& Bermejo-Sánchez, 2016).

Family succession is the fifth characteristic that influences business families. Family firms often seek to preserve the business for the next generation (Zellweger, 2007). Family succession consists of the incumbent generation failing to actively participate in functions in the firm's structure and to succeed, whether by its heirs or not (Chrisman, Chua, \& Steier, 2003).

The sixth and last feature addressed is control retention. As previously explained, an integral part of the definition of a family business is the control that business families have (Anderson $\&$ Reeb, 2003; Martínez-Ferrero, Rodríguez-Ariza, \& Bermejo-Sánchez, 2016). In addition to having control, it is in their interest to build a legacy and pass it on to future generations, so maintaining control becomes a priority (Chen \& Hsu, 2009; Cucculelli, Breton-Miller, \& Miller, 2016).

These characteristics of the family firm predispose it to some peculiarities, especially as to which decisions will be made by managers (Naldi et al., 2007). Unlike the extensive literature on family firms, which seeks to analyze differences in performance when compared to unfamiliar firms, this paper aims to identify a distinct stance for family firms in the risk-taking construct.

\subsection{RISK-TAKING}

In the research line that addresses risk, it is common to find studies on the behavior of agents about risk-taking (Coles et al., 2006). The risk for decision making refers to the probabilistic uncertainty of the returns derived from a choice (March \& Shapira, 1987). This section discusses the catalytic incentives of decisions from the perspective of the economic agent.

The study of risk decision making was first approached in 1738 by the Swiss mathematician Daniel Bernoulli when he studied the reaction of individuals to betting proposals. He was the first to study what would become the Utility Maximization Theory, noting that people were not always looking for the highest possible monetary gain when making decisions affected by uncertainty, but rather maximizing its utility. The utility would represent, in economic terms, the personal satisfaction of the agent. 
In the twentieth century, von Neumann and Morgenstein (1945) reignited interest in the topic when they reformulated the theory of utility maximization. Since then, this theory has been present in risk studies and risk decision making (Zyphur et al., 2009). Arrow (1952) and Allais (1953) incorporated the notion of risk into classical economic ideas. They changed the concept of decision making by identifying risk as a determining factor in the decisions that economic agents make. They must make each decision from a set of alternatives, according to their motivations, expectations, and incentives (Atkinson, 1957). This behavior varies according to the economic characterization of the decision-maker. Particularities may predispose some to be more risk-averse, while others would prefer to incur more risk in pursuit of higher returns.

The maximizing utility agent is known as Homo Economicus, which, in economic theories, represents the human being as consistently rational and self-interested, always looking for the optimal allocation point for his goals (Thaler \& Sunstein, 2009). This high point is based on his concept of utility. Economic rationality assumes that, once exposed to all choice alternatives, the agent can sort them by their preferences. Assuming that the agent is perfectly rational implies that he would have accurate and comprehensive economic knowledge, different from what is shown by empirical evidence. Economic studies applied this concept in the most diverse analyzes extensively.

With the advance of economic science, inconsistencies in the assumption of the rationality of agents began to be highlighted in several lines of research. Several factors that make the human being not act following the maximizing rational behavior of utility have been identified. One of the lines of research that stood out most for criticizing the idea of utility maximization was Behavioral Economics, which exposes how humans systematically make their decisions, which are often contradictory and do not maximize utility (Kahneman \& Tversky, 1979). In addition to systematically differing from the classic rational agent, the behavior of individuals would also differ from each other according to their particularities (Guay, 1999).

Then, factors beyond utility maximization and the economic realm influenced the decisionmaking process, allowing profiling and analysis of behavior patterns. Research that analyzes decisions from the perspective of risk-taking seeks to understand how agents behave differently depending on their decision alternatives and characteristics. These can range from personal traits to the way the firm is structured (Chen \& Vann, 2017).

These deviations from theory open interpretation to the subjectivity of the decision, which makes it even more relevant to understand the agent who makes the decision and its incentives. This intra-agent heterogeneity is also present in decision-makers in publicly traded firms. These may be different due to several factors, highlighting the type of ownership and control of the firm (Fernandez \& Nieto, 2006). The next section reviews empirical work on the risk-taking behavior of family firms and elaborates the research hypothesis.

\subsection{Risk-Taking in Family Business}

As explained in the previous section, factors beyond utility maximization and the economic realm influence the decision-making process. The reviewed literature points out how the personal profile of each decision-maker affects behavior (Atkinson, 1957; John et al., 2008). In deciding between various alternatives, he acts according to his motivations, expectations, and incentives. These may be motivated by their benefits, aligning their equity with the firm's results and taking riskier positions, as well as by the stability of their particular situation, in this case, presenting more conservative behavior. 
BBR

17

404

There is a lack of literature addressing the circumstance in which risk-taking is influenced by the presence of a business family in the firm (Memili et al., 2010). An empirical line of research gives family firms the risk aversion character. Given the concentration of the business family's equity invested, the firm would choose to prioritize the firm's long-term survival over potential entrepreneurial opportunities that include risk, for example. This fact implies that their decisions are made with continuity in mind and not just seeking short-term returns, but many publicly traded firms are under pressure to operate (de Vries, 1993).

Also contributing to risk aversion is the preservation of Family Socio-Emotional Heritage (FSH), which comprises several non-economic objectives (Laffranchini \& Braun, 2014). The FSH manifests itself in some ways, such as identification with the firm or altruism among members of the business family. The loss of the FSH implies a loss of recognized status in society and in the family nucleus, and a feeling of failure in relation to the family expectations.

Taking into consideration the reviewed works and the relevance of the theme, the following research hypothesis is formulated:

- H1: Family firms have greater risk aversion than non-family firms.

Every decision made by the business family is connected with family equity, which influences the activities the firm engages in (Memili et al., 2011). Concentrating family equity in the firm helps to create long-term relationships with other shareholders and clients (Memili et al., 2010). With undiversified capital predominantly invested in the firm, one can expect that the motivation of the business family to create a legacy for their image and subsequent generations is greater than that of, for example, managers with no capital invested in the firm. (Chen \& Hsu, 2009). This concentration of equity facilitates the alignment of shareholders' interests so that decisions are made with less conflict and bureaucracy (Carrasco-Hernandez \& Sánchez-Marín, 2007).

The concentration of equity also increases the ability to monitor the business of the business family, participating more actively in decisions than other types of shareholders (Braun; Sharma, 2007). It summarizes the shareholding position of the business family as lightly diversified, focusing on the family business and consequently aligned with its financial performance. In this context, one can expect that family business to have higher risk aversion than non-family firms, as the family business is the shareholder with the most significant potential for loss, either in terms of return or equity invested in the firm. This phenomenon can occur because there is a concomitance between the economic position of the firm and the business family. This undiversified equity position of the business family results in a differentiated stance towards decisions made (Huybrechts et al., 2013).

To empirically test the hypothesis formulated, the econometric methodology set out in the next chapter was applied.

\section{METHODOLOGY AND SAMPLE}

We perform three econometric procedures: a mean difference test, a research hypothesis test, and an average treatment effect estimation (Davidson \& Mackinon, 2004). The objective of the first test is to verify if the variables behave in a statistically distinct manner according to the firm's status: familiar or not.

The second econometric procedure is an Ordinary Least Squares (OLS) regression model that aims to test the research hypothesis. For this, we run the model specified in Equation, in which we control for firms' characteristics to isolate the effect of family presence on firms' risk-taking. 
We use eight distinct combinations of variables in the OLS tests, and therefore the same number of different regressions are run for this model.

$$
\text { Risk-Taking }_{\mathrm{t}}=\beta_{0}+\beta_{1} \text { Family }_{\mathrm{t}}+\beta_{2} \text { Controls }_{\mathrm{t}}+\varepsilon
$$

Where:

Risk-Taking $_{\mathrm{t}}=$ risk-taking of firms in period $\mathrm{t}$.

Family $_{\mathrm{t}}=$ variable that indicates the family presence in the firm in period $\mathrm{t}$.

Controls $s_{\mathrm{t}}=$ model's control variables in period $\mathrm{t}$.

$\varepsilon=$ regression error term.

$\beta_{1}$ is the parameter of interest of the research, indicating the relationship between family presence and risk-taking. Its negative statistical significance would suggest that the family's presence has a negative impact on the dependent variable, risk-taking, and consequently that the family firm would be averse to taking risks. The opposite is also valid; that is, if the parameter is positive, the family presence in firms would indicate a higher propensity to take risks. In the absence of statistical significance, there would be no evidence that family firms behave differently from unfamiliar firms.

To construct the dependent variable, which seeks to express the level of risk-taking of firms, we use a methodology derived from that applied in John, Litov and Yeung (2008) and Faccio, Marchica and Mura (2011). Return on asset volatility (ROA) is measured over a four-year period, i.e., from $t$ to $t+3$. We present the rationale used to calculate the ROA in Equation 2 .

$$
R O A_{\mathrm{t}}=E B I T D A_{\mathrm{t}} / \text { Total Asset }
$$

Where:

$E B I T D A_{\mathrm{t}}=$ indicates earnings before interest, taxes, depreciation, and amortization in the firm in period $\mathrm{t}$.

Total Asset t $_{\mathrm{t}}$ Total assets of the firm in period $\mathrm{t}$.

The firm's configuration at $\mathrm{t}$ is assumed to imply decisions that influence risk-taking levels in subsequent periods. Therefore, the ROA volatility in the three years following the firm's period $t$ is assessed. That is, we believe that the decision made at the period $t$ will influence future results (from $t$ to $t+3$ ). To control the effects of each industry, we use the average ROA of each industrial segment present in B3 in the period analyzed. The industry classification used was the one defined by B3. Subtract from each firm's ROA the average ROA of their respective industry over the same period, and then calculate the standard deviation of this difference using the values between $t$ and $t+3$. In short, this measure is assessing how much that company varies more or less its result compared to its peers, and this phenomenon is a proxy for risk-taking. Equation 3 indicates how the risk-taking measure is calculated using ROA.

$$
\text { Risk-Taking }_{\mathrm{t}}=\sigma\left(R O A_{[\mathrm{t}, \mathrm{t}+3]}-\overline{R O A}-\operatorname{Ind}_{[\mathrm{t}, \mathrm{t}+3]}\right)
$$

The choice for this variable construction that represents risk-taking in this work is a differential of the research. Previous researches that studied family firms and risk-taking mostly used Research and Development as a proxy for risk-taking (Chen \& Hsu, 2009). In addition to removing the influence of each industry's particularities, this generates a risk-taking measure that is particularly focused on firm decisions (John, Litov, \& Yeung, 2008; Faccio, Marchica, \& Mura, 2011).

The independent variables seek to explain the dependent variable, being divided between interest and control. The variable of interest aims to represent the family presence in the firm. 
BBR

17

406

Control variables include other effects that the econometric model seeks to isolate that influence risk-taking.

The research variable of interest classifies the firm as familiar or non-familiar. For this, a dummy variable is used, which assumes the value of 1 if the firm is considered familiar and 0 if it is not. To be classified as a family, a firm must meet two criteria following the notions previously addressed in the literature review. The first criterion is that it has at least one member of the business family as a controlling shareholder. Firms disclosure of the definition of the controller in their Reference Forms, section 15.1 / 15.2. Due to legal obligations that firms must comply with to be listed on the Brazilian stock market, they periodically disclose information that discriminates which shareholders are their shareholders and which are their controlling shareholders. The second criterion requires the firm's controller to appoint at least one member to the board of directors in that period. In line with the notion that it is not enough to have a concentration of a business family for the firm to be considered family, we assume that there is also active involvement in the firm. Therefore, available information about who are the members of the firm's board of directors is used, specifying if and which members the controller appointed. These would represent the interests of the business family on the board of directors. This definition of family presence makes up the Fam1 variable.

However, as discussed in the literature review, the definition of the family name is broad and has no consensus. Therefore, we elaborate on an alternative variable that seeks to express the family status of the firm: Fam2. This variable is less rigid than Fam1, with only one criterion: having at least one member of the business family as a controlling shareholder. Assuming that family firms behave differently than non-familar firms, we expect the effect to be less pronounced when using a variable that is less restrictive of family characteristics (Villalonga \& Amit, 2006).

Many variables are included in the econometric calculation to control the effect of other factors that influence firms' risk-taking (summarized in Table 1). We seek to control the following characteristics of firms' observations: performance (ratio of net income to equity), size (log of total assets), number of board members, external proportion, investment opportunities ( sum of the firm's market value + total debt divided by total assets), liquidity (cash flow divided by total assets), life cycle (explained below), stock return and the year of observation (John, Litov, \& Yeung, 2008; Chen \& Hsu, 2009; Dickinson, 2011; Faccio, Marchica, \& Mura, 2011; Kuang \& Qin, 2013; Avrichir, Meneses, \& Santos, 2016; Vancin \& Procianoy, 2016).

By using a variable to represent the life cycle of each firm, one controls for differences in the stage of development the firm is in, as the risk-taking level is expected to decrease with the firm's age. It also helps to control factors such as product maturation and learning and experience curves. We use two distinct variables to try to capture the life cycle effect. The first variable that seeks to control this relationship is called Age, and its calculation represents the number of years since the company's IPO (Dickinson, 2011; Faccio, Marchica, \& Mura, 2011).

Another proxy that seeks to capture the life cycle uses a methodology derived from Dickinson (2011). We use cash flow from operations (CFO), investments (CFI), and financing activities (CFF). According to the value of each of these three variables, we classify the firm's life cycle into Introduction, Growth, Maturation, Decline, and Reorganization. We use dummy variables to identify each of these stages in the regression model, which assumes the value 1 when the criterion of each variable is met. Their calculations are spelled out in Equations 4, 5, 6, 7, and 8. 


$$
\begin{gathered}
\text { Introduction }_{\mathrm{t}}=C F O<0, C F I<0 \text { and } C F F>0 \\
\text { Growth }_{\mathrm{t}}=C F O>0, C F I<0 \text { and } C F F>0 \\
\text { Maturation }_{\mathrm{t}}=C F O>0, C F I<0 \text { and } C F F<0 \\
\text { Decline }_{\mathrm{t}}=C F O<0, C F I>0 \text { and } C F F>=0 \text { ou }<=0 \\
\text { Reorganization }_{\mathrm{t}}=\text { all remaining settings }
\end{gathered}
$$

\begin{tabular}{|c|c|c|c|}
\hline Variable & Equation & References & Theoretical Reason \\
\hline Size & $\begin{array}{l}\text { Natural Logarithm of } \\
\text { Total Assets of firm at t. }\end{array}$ & $\begin{array}{l}\text { Zahra 2005; Chrisman } \\
\text { \& Patel, 2012; Vancin \& } \\
\text { Procianoy, 2016. }\end{array}$ & $\begin{array}{l}\text { The larger the firm, the more likely it } \\
\text { is to resist change and innovation. }\end{array}$ \\
\hline Performance & $\begin{array}{l}\text { Ratio between net income } \\
\text { and equity. }\end{array}$ & $\begin{array}{l}\text { Zahra, 2005; Faccio, } \\
\text { Marchica, \& Mura, } 2011 .\end{array}$ & $\begin{array}{l}\text { A recent successful track record } \\
\text { would inhibit managers from } \\
\text { pursuing risky entrepreneurial } \\
\text { activities given their satisfaction with } \\
\text { the firm's situation. }\end{array}$ \\
\hline Board & $\begin{array}{l}\text { Number of board } \\
\text { members. }\end{array}$ & $\begin{array}{l}\text { Goodstein, Gautam, \& } \\
\text { Boeker, } 1994 \text { e Zahra et } \\
\text { al., } 2000 .\end{array}$ & $\begin{array}{l}\text { It is considered more difficult to } \\
\text { make risky decisions when the } \\
\text { quorum that decide is higher. }\end{array}$ \\
\hline External & $\begin{array}{l}\text { Ratio between the number } \\
\text { of external directors and } \\
\text { the existing total. }\end{array}$ & $\begin{array}{l}\text { Anderson \& Reeb, } 2004 \text { e } \\
\text { Chen \& Hsu, } 2009\end{array}$ & $\begin{array}{l}\text { This feature influences how much } \\
\text { management is monitored and allows } \\
\text { the inclusion of views of members } \\
\text { outside the firm's routine. }\end{array}$ \\
\hline Opportunities & $\begin{array}{l}\text { Sum of market value and } \\
\text { debt divided by total } \\
\text { assets. }\end{array}$ & $\begin{array}{l}\text { Smith \& Stulz, 1985; } \\
\text { Kammler \& Alves, } 2009 \text { e } \\
\text { Belkhir \& Chazi, } 2010 .\end{array}$ & $\begin{array}{l}\text { The more investment opportunities, } \\
\text { the more the firm would tend to } \\
\text { get involved with new projects and } \\
\text { would be backed by risk-taking. }\end{array}$ \\
\hline Liquidity & $\begin{array}{l}\text { Cash Flow divided by } \\
\text { Total Assets. }\end{array}$ & $\begin{array}{l}\text { Chen \& Hsu, 2009; } \\
\text { Muñoz-Bullón \& } \\
\text { Sanchez-Bueno, } 2011 .\end{array}$ & $\begin{array}{l}\text { It is expected that the more liquidity } \\
\text { the firm has, the more predisposed it } \\
\text { will be to take risks, and vice versa. }\end{array}$ \\
\hline Age & $\begin{array}{l}\text { Number of years since } \\
\text { foundation. }\end{array}$ & $\begin{array}{l}\text { Dickinson, } 2011 \text { e Faccio, } \\
\text { Marchica \& Mura, } 2011 .\end{array}$ & $\begin{array}{l}\text { The risk-taking level is expected to } \\
\text { decrease with the firm's age. }\end{array}$ \\
\hline Return & $\begin{array}{l}\text { Share price in } \mathrm{t} \text { divided } \\
\text { by the price in } \mathrm{t}-1 \text { minus } \\
\text { one. }\end{array}$ & $\begin{array}{l}\text { Kuang \& Qin, } 2013 \text { e } \\
\text { Elsilä, } 2015\end{array}$ & $\begin{array}{l}\text { Higher risk companies, on average, } \\
\text { should have higher returns. }\end{array}$ \\
\hline
\end{tabular}

Table 1

Control Variables

Source: Prepared by the authors.

The third test used seeks to estimate the average treatment effect. We performed this test to complement the Ordinary Least Squares regressions. Using the same variables elaborated for the OLS, we separated the sample between two groups: family firms (treatment) and non-family firms (control). Again the variables Fam1 and Fam 2 were used to make this distinction. Each family firm is paired, and this process was performed according to the highest possible similarity between the values of control variables. Using this mechanism, known as propensity score matching, we sought to observe the impact of family presence on the dependent variable, Risk-Taking. 
BBR

17

408

According to the sign of the verified coefficient, it can be attested whether there is evidence of a statistically significant impact, whether positive or negative, of family presence in risk-taking.

Finally, the last part to be approached by the methodology employed is the sample. It contains the open-ended firms of the Brazilian stock market, B3, active in all or part of the period 20102017. Data were collected from 2010 onwards, as it was from this period that Brazil adhered to the International Financial Reporting Standards (IFRS), making it possible to obtain standardized information. We collect all information used from two data sources.

The first one consists of the Reference Forms provided by the Brazilian Securities Commission (CVM). All information collected is contained in sections 12, Assembly and Administration, and 15, Control and Economic Group. By processing the data in the RStudio statistical software, which uses R programming, it was possible to organize the information about the business families. Data collection was mechanized by obtaining, through the GetDFPData package (Perlin, Kirch, \& Vancin, 2018), all necessary information from the Reference Forms.

We obtained the rest of the information through the Economatica software. Regarding the information used from this source, and to simplify the interpretation of the results, all data collected with its quotation in reais $(\mathrm{R} \$)$ were divided by 1,000 , to alleviate the magnitude of the calculations (Villalonga \& Amit, 2006). All observations that did not have complete market value data were also disregarded. Finally, winsorize all information collected at a level of $2.5 \%$ before calculating each variable, to exclude possible outliers from the sample. Following the suggestions of an anonymous reviewer and as a robustness test, we re-estimated our original regressions using the $1 \%$ parameter in winsorization. The results remained unchanged.

The initial sample consisted of 1,737 observations from publicly traded Brazilian companies listed in B3. Of these, 455 did not have data for the liquidity variable, and 94 did not have enough information to construct the other variables. Thus, the final sample consists of 1188 observations. Of the 1188 observations in the sample, 431 refer to family firms according to the Fam 1 variable criterion. This data indicates that $36.28 \%$ of the firms in the sample are family members. Table 2 shows the ratio between family and non-family firms each year collected. In all sample years, we can observe a predominance of non-family firms, which represent over $60 \%$ of the firms analyzed.

Table 2

Sample

\begin{tabular}{|c|c|c|c|c|c|}
\hline Year & Family Firms & $\% \mathrm{FF}$ & Non-Family Firms & $\% \mathrm{NFF}$ & Total \\
\hline \multicolumn{6}{|c|}{ Panel A: Fam 1 criterion } \\
\hline 2010 & 92 & $39,48 \%$ & 141 & $60,52 \%$ & 233 \\
\hline 2011 & 78 & $33,62 \%$ & 154 & $66,38 \%$ & 232 \\
\hline 2012 & 77 & $32,22 \%$ & 162 & $67,78 \%$ & 239 \\
\hline 2013 & 93 & $38,91 \%$ & 146 & $61,09 \%$ & 239 \\
\hline 2014 & 91 & $37,14 \%$ & 154 & $62,86 \%$ & 245 \\
\hline Total & 431 & $36,28 \%$ & 757 & $63,72 \%$ & 1188 \\
\hline \multicolumn{6}{|c|}{ Panel B: Fam 2 criterion } \\
\hline 2010 & 97 & $41,63 \%$ & 136 & $58,37 \%$ & 233 \\
\hline 2011 & 82 & $35,34 \%$ & 150 & $64,66 \%$ & 232 \\
\hline 2012 & 80 & $33,47 \%$ & 159 & $66,53 \%$ & 239 \\
\hline
\end{tabular}




\begin{tabular}{lccccc}
\hline Year & Family Firms & $\%$ FF & Non-Family Firms & $\%$ NFF & Total \\
\hline 2013 & 96 & $40,17 \%$ & 143 & $59,83 \%$ & 239 \\
2014 & 94 & $38,37 \%$ & 151 & $61,63 \%$ & 245 \\
Total & 448 & $37,79 \%$ & 740 & $62,21 \%$ & 1188 \\
\hline
\end{tabular}

Source: Prepared by the authors.

After the description of the proposed methodology, the next chapter presents the results obtained.

\section{RESULTS}

This chapter presents the results of the work. Firstly, we address the descriptive statistics of the sample as a whole. Afterward, we distinguish family firms from non-family firms by performing the T-test for mean differences. Then, the hypothesis is tested empirically through an Ordinary Least Squares model. Finally, we present the results of the average treatment effect estimation.

The complete sample contains 1188 observations. Descriptive statistics for all non-dummy variables used are presented in Table 3. The dependent variable generally has values close to zero. It is in the interest of risk-averse managers that this value should be as low as possible. We observe that the average amount is 0.601 , higher than the median, and even the value that delimits the third quartile, given the existence of larger proportions that consequently raise the average.

Table 3

Descriptive Statistics

\begin{tabular}{lccccccc}
\hline Statistic & Min. & $1^{\circ} \mathrm{Q}$. & Median & Mean & $3^{\circ} \mathrm{Q}$. & Max. & $\sigma$ \\
\hline Risk-Taking & 0.004 & 0.046 & 0.077 & 0.601 & 0.308 & 28.108 & 0.449 \\
Size & 0.699 & 5.549 & 6.238 & 5.996 & 6.724 & 8.899 & 1.336 \\
Performance & -56.11 & 0.006 & 0.089 & -0.07 & 0.185 & 29.476 & 24.832 \\
Board & 1 & 7 & 13 & 14.27 & 19 & 52 & 11.68 \\
External & 0.000 & 0.000 & 0.034 & 0.093 & 0.167 & 1 & 0.112 \\
Opportunities & 0.000 & 0.381 & 0.718 & 1.18 & 1.22 & 57.819 & 5.326 \\
Liquidity & -21.0 & 0.018 & 0.083 & -0.072 & 0.143 & 3.174 & 0.005 \\
Age & 0.0 & 13 & 31 & 37.63 & 57 & 144 & 8.764 \\
Return & -84.27 & -14.905 & 0.000 & 2.147 & 11.131 & 502.311 & 27.43 \\
\hline
\end{tabular}

Source: Prepared by the authors.

The Size variable, being a logarithmic function, has proportionally close values. We observe an average value of 5.996 and a median of 6.238. The Performance variable has a mean value of -0.007 and a median of 0.089 . Some observations show a considerable Net Income magnitude compared to the Net Equity value, either positive or negative. Therefore, this variable has proportionally different values from the mean. The cutoff value of the first quartile indicates that most values for this variable are positive. The standard deviation value indicates that the second and third integer quartiles are within one standard deviation.

Regarding the variable Boards, we observed that all firms in the sample have at least one board member. Several firms have only one, while Duratex in 2010 has the most significant number: 
BBR

17

410

52. On average, firms have 14.27 board members, with a median of 13 . The values of the 1 st quartile, the average, and the 3rd quartile allow us to infer the cutoff values for the alternative methodology that seeks to control the impact of the number of advisors. The first quartile comprises firms that have from one to seven directors, the second quartile from seven to 13 , the third from 13 to 19 members, and the fourth from 19 to the previously mentioned maximum of 52. Among the board members, on average, approximately one every twelve are external to the firm, which configures a predominance of directors who are already part of the firm's dynamics. At least $25 \%$ of firms do not have external members on their board. Councils made up mostly of external members are an exception regime. This fact would configure a higher possibility of risk-taking approval (Chen; Hsu, 2009).

The Opportunities variable has an average of 1.18 , higher than the median of 0.718 . This proportional discrepancy would probably occur due to an increase of observations in the right tail of this distribution, which influences the observed standard deviation. Finally, we can infer that more firms have positive than negative values for their investment opportunities. The Liquidity variable is one of two variables that has a negative average of the entire sample, with an amount of -0.072 . This phenomenon would indicate that, in the period under review, the firms encountered considerable financial difficulties. Even with winsorization, some values proportionally stand out, whether positive or negative. Its median attests that most firms had positive liquidity in the period.

Firms, on average, are 37.63 years old, which implies, from a family perspective, that the founder would already be old enough to have successors. The minimum value of 0 years is explained by some firm's segmentation, which were restructured when already listed in the stock exchange. Given the advanced age values of some firms, the standard deviation value is more significant than average. The Return variable represents a firm's behavior towards the market. On average, firms posted a return of $2.147 \%$ per year. The median found of zero is explained by low liquidity stocks that do not show the turnover captured by Economática in the period in which the return is calculated. The lowest performance in one year was $-84.27 \%$ (OSX in 2013). On the other hand, PET Manguinhos grew 502.31\% in 2010.

The mean difference tests were performed, presented in Table 4. We estimated the T-test for all non-dummy independent variables. As indicated by the results, we observed that six variables have significant statistical differences between the average values of family and non-family firms when evaluated by the T-test. The variables Size, Liquidity, Opportunities, Age, Board, and External, presented a mean difference between a statistical significance of $1 \%$.

Table 4

Mean Difference T-test

\begin{tabular}{lccc}
\hline Variables & Mean FF & Mean NFF & p-value \\
\hline Size & 6.234 & 5.736 & 0.000 \\
Performance & 0.081 & 0.061 & 0.538 \\
Board & 14.789 & 13.299 & 0.005 \\
External & 0.099 & 0.075 & 0.001 \\
Opportunities & 1.249 & 0.730 & 0.002 \\
Liquidity & 0.051 & -0.109 & 0.000 \\
Age & 41.266 & 36.366 & 0.004 \\
Return & 0.046 & 0.325 & 0.879 \\
\hline
\end{tabular}

Source: Prepared by the authors. 
The results indicated that family firms would present variables with statistically distinct values from unfamiliar firms. These results corroborate the notion that family firms behave peculiarly, justifying their study as an object of their research (Gallo; Vilaseca, 1996; Poutziouris; Smyrnios; Klein, 2008; Borges; Lescura; Oliveira, 2012).

The next test performed was the hypothesis test using Ordinary Least Squares. We configured eight regressions with different combinations of independent variables. Regressions 1 through 4 apply the Fam 1 criterion for family presence. In this group of models, the proxies representing the number of board members - "Board" or "Quartile," and the stage of the company's life cycle - "Age" or "Introduction / Growth / Maturation / Decline" vary. In regressions from 5 to 8, we used the Fam 2 criterion as a variable of interest, and the proxies cited for Fam 1 also vary.

In the four procedures using Fam1, the presented coefficient of the variable of interest was negative, which would imply that the family presence would cause a lower risk-taking. These results are significant at a level of $1 \%$.

By expanding the concept of family firms to the Fam 2 criterion, the results remain similar. The coefficients presented by the variable of interest in regressions 5 to 8 are always negative, and, as in Fam 1, are significant at a level of 1\%. All combinations with Ordinary Least Squares present the expected coefficient for family presence at a level of statistical significance of $1 \%$, which would corroborate the hypothesis that family firms would be more risk-averse than non-family firms.

In all regressions performed, the coefficient of the variable expressing family presence in the firm was negative. There would be evidence that family presence in firms would lead to higher risk aversion.

Control variables were also analyzed in the OLS (Table 5) tests that presented a level of statistical significance. The Size variable had a negative impact on risk-taking according to the coefficient found in the eight regressions. This result is in line with the literature that argues that larger firms make greater risk-taking impossible because of their large and bureaucratic structure.

Table 5

Hypothesis Test: Ordinary Least Squares

\begin{tabular}{|c|c|c|c|c|c|c|c|c|}
\hline & (1) & (2) & (3) & (4) & (5) & (6) & (7) & (8) \\
\hline \multicolumn{9}{|l|}{ Variables } \\
\hline \multirow[t]{2}{*}{ Fam 1} & $-99.34^{* * *}$ & $-99.31^{* * *}$ & $-93.05^{* * *}$ & $-93.48^{* * *}$ & & & & \\
\hline & $(-5.40)$ & $(-5.46)$ & $(-5.12)$ & $(-5.21)$ & & & & \\
\hline \multirow[t]{2}{*}{ Fam2 } & & & & & $-89.72^{* * *}$ & $-87.28^{* * *}$ & $-83.51^{* * *}$ & $-81.59^{* * *}$ \\
\hline & & & & & $(-4.82)$ & $(-4.74)$ & $(-4.54)$ & $(-4.49)$ \\
\hline \multirow[t]{2}{*}{ Performance } & 0.05 & 0.03 & 0.02 & 0.01 & 0.04 & 0.03 & 0.02 & 0.01 \\
\hline & (1.39) & $(0.90)$ & $(0.63)$ & $(0.21)$ & (1.33) & $(0.85)$ & $(0.57)$ & $(0.16)$ \\
\hline \multirow[t]{2}{*}{ Size } & $-0.16^{* * *}$ & $-0.07^{* *}$ & $-0.11^{* * *}$ & -0.02 & $-0.16^{* * *}$ & $-0.08^{* *}$ & $-0.11^{* * *}$ & -0.02 \\
\hline & $(-5.64)$ & $(-2.29)$ & $(-3.69)$ & $(-0.72)$ & $(-5.63)$ & $(-2.37)$ & $(-3.67)$ & $(-0.77)$ \\
\hline \multirow[t]{2}{*}{ Board } & $1.32^{* *}$ & & $1.13^{* *}$ & & $1.27^{* *}$ & & $1.07^{*}$ & \\
\hline & $(2.29)$ & & $(1.96)$ & & $(2.18)$ & & $(1.86)$ & \\
\hline \multirow[t]{2}{*}{$1^{\text {st }}$ Quartile } & & $168.12^{* * *}$ & & $171.41^{* * *}$ & & $163.42^{* * *}$ & & $167.32^{* * *}$ \\
\hline & & $(5.43)$ & & $(5.64)$ & & $(5.26)$ & & $(5.49)$ \\
\hline \multirow[t]{2}{*}{$2^{\text {nd }}$ Quartile } & & 34.47 & & $50.61^{*}$ & & 32.15 & & $48.76^{*}$ \\
\hline & & $(1.26)$ & & $(1.87)$ & & (1.17) & & $(1.80)$ \\
\hline \multirow[t]{2}{*}{$3^{\text {rd }}$ Quartile } & & 13.63 & & 27.49 & & 11.32 & & 25.67 \\
\hline & & $(0.53)$ & & (1.08) & & $(0.44)$ & & (1.01) \\
\hline
\end{tabular}


BBR

17

412
Table 5

Cont.

\begin{tabular}{|c|c|c|c|c|c|c|c|c|}
\hline & (1) & (2) & (3) & (4) & (5) & (6) & (7) & (8) \\
\hline \multirow[t]{2}{*}{ External } & -0.50 & -0.41 & -0.41 & -0.33 & $-0.51^{*}$ & -0.42 & -0.42 & -0.34 \\
\hline & $(-1.64)$ & $(-1.34)$ & $(-1.35)$ & $(-1.12)$ & $(-1.68)$ & $(-1.38)$ & $(-1.37)$ & $(-1.14)$ \\
\hline \multirow[t]{2}{*}{ Opportunities } & 0.01 & 0.03 & -0.01 & 0.01 & 0.01 & 0.02 & -0.01 & 0.00 \\
\hline & $(0.47)$ & $(0.87)$ & $(-0.19)$ & $(0.23)$ & $(0.43)$ & $(0.82)$ & $(-0.24)$ & $(0.17)$ \\
\hline \multirow[t]{2}{*}{ Liquidity } & $-0.32^{* * *}$ & $-0.30^{* * *}$ & $-0.27^{* * *}$ & $-0.26^{* * *}$ & $-0.32^{* * *}$ & $-0.30^{* * *}$ & $-0.27^{* * *}$ & $-0.26^{* * *}$ \\
\hline & $(-9.32)$ & $(-8.81)$ & $(-7.22)$ & $(-6.96)$ & $(-9.32)$ & $(-8.81)$ & $(-7.22)$ & $(-6.97)$ \\
\hline \multirow[t]{2}{*}{ Age } & $-1.47^{* * *}$ & $-1.29^{* * *}$ & & & $-1.50^{* * *}$ & $-1.32^{* * *}$ & & \\
\hline & $(-5.28)$ & $(-4.64)$ & & & $(-5.37)$ & $(-4.77)$ & & \\
\hline \multirow[t]{2}{*}{ Introduction } & & & $-241.91^{* * *}$ & $-229.11^{* * *}$ & & & $-245.43^{* * *}$ & $-233.14^{* * *}$ \\
\hline & & & $(-7.29)$ & $(-6.98)$ & & & $(-7.38)$ & $(-7.08)$ \\
\hline \multirow[t]{2}{*}{ Growth } & & & $-186.61^{* * *}$ & $-170.48^{* * *}$ & & & $-189.22^{* * *}$ & $-173.62^{* * *}$ \\
\hline & & & $(-6.25)$ & $(-5.77)$ & & & $(-6.33)$ & $(-5.86)$ \\
\hline \multirow[t]{2}{*}{ Maturation } & & & $-183.15^{* * *}$ & $-168.80^{* * *}$ & & & $-184.90^{* * *}$ & $-170.89^{* * *}$ \\
\hline & & & $(-6.43)$ & $(-5.99)$ & & & $(-6.48)$ & $(-6.05)$ \\
\hline \multirow[t]{2}{*}{ Decline } & & & $-109.22^{* *}$ & $-106.53^{* *}$ & & & $-113.33^{* *}$ & $-110.43^{* *}$ \\
\hline & & & $(-2.37)$ & $(-2.35)$ & & & $(-2.46)$ & $(-2.43)$ \\
\hline \multirow[t]{2}{*}{ Return } & 0.01 & 0.01 & 0.02 & 0.01 & 0.01 & 0.01 & 0.02 & 0.01 \\
\hline & $(0.31)$ & $(0.18)$ & $(0.41)$ & $(0.29)$ & $(0.31)$ & $(0.19)$ & $(0.42)$ & $(0.30)$ \\
\hline \multirow[t]{2}{*}{2011} & -29.56 & -27.53 & -34.50 & -32.92 & -28.75 & -26.51 & -33.92 & -32.14 \\
\hline & $(-1.05)$ & $(-0.99)$ & $(-1.24)$ & $(-1.20)$ & $(-1.02)$ & $(-0.95)$ & $(-1.22)$ & $(-1.17)$ \\
\hline \multirow[t]{2}{*}{2012} & -36.29 & -40.15 & $-52.91^{*}$ & $-56.40^{* *}$ & -34.89 & -38.34 & $-51.89^{*}$ & $-55.05^{* *}$ \\
\hline & $(-1.30)$ & $(-1.45)$ & $(-1.91)$ & $(-2.07)$ & $(-1.25)$ & $(-1.39)$ & $(-1.87)$ & $(-2.01)$ \\
\hline \multirow[t]{2}{*}{2013} & 16.42 & 24.24 & -6.58 & 3.38 & 17.22 & 24.94 & -6.35 & 3.48 \\
\hline & $(0.58)$ & $(0.87)$ & $(-0.24)$ & $(0.12)$ & $(0.61)$ & $(0.90)$ & $(-0.23)$ & $(0.13)$ \\
\hline \multirow[t]{2}{*}{2014} & 30.61 & 40.56 & 1.08 & 12.77 & 31.55 & 41.42 & 1.30 & 12.87 \\
\hline & (1.09) & (1.46) & $(0.04)$ & $(0.46)$ & (1.12) & (1.49) & $(0.05)$ & $(0.46)$ \\
\hline \multirow[t]{2}{*}{ Constant } & $1,055.53^{* * *}$ & $734.85^{* * *}$ & $1,808.07^{* * *}$ & $1,399.75^{* * *}$ & $1,045.74^{* * *}$ & $734.35^{* * *}$ & $1,810.82^{* * *}$ & $1,410.57^{* * *}$ \\
\hline & $(21.87)$ & $(6.74)$ & (13.80) & (8.78) & (21.51) & $(6.69)$ & (13.78) & $(8.82)$ \\
\hline Observations & 1,188 & 1,188 & 1,188 & 1,188 & 1,188 & 1,188 & 1,188 & 1,188 \\
\hline $\mathrm{R}^{2}$ & 0.2240 & 0.2475 & 0.2468 & 0.2691 & 0.2201 & 0.2428 & 0.2432 & 0.2648 \\
\hline
\end{tabular}

Ordinary Least Squares - Control by Industry; t-value in parentheses; ${ }^{* * *} \mathrm{p}<0.01,{ }^{* *} \mathrm{p}<0.05,{ }^{*} \mathrm{p}<0.1$

Source: Prepared by the authors.

When analyzing the impact of the number of board members on risk-taking, the "Board" and "Quartile 1" proxies indicate statistical significance. "Board" presented positive coefficients in the four regressions in which it is employed, in line with the revised literature on the propensity for risk-taking by family firms. These results are significant at a level of 5\% in regressions 1 and 5 and $10 \%$ in regressions 3 and 7 . Analyzing the dummy variables that sought to express this relationship, only the Quartile 1 variable showed statistical significance at a level of $1 \%$.

The External variable presented in the eight regressions tested a negative coefficient. This fact would attest that the higher the number of external board members, the lower the risk-taking assumed by the company, as evidenced by the literature review. This result was statistically 
significant at a level of $10 \%$. The Liquidity variable presented a negative and significant coefficient at a level of $1 \%$ in the eight regressions tested. This result contradicts the notion that more liquid firms would be more likely to take risks.

Finally, we sought to control the effect of the firm's life cycle on risk-taking. The variable Age presented negative coefficients in the four regressions in which it is used at a level of statistical significance of $1 \%$. That is, the older the firm, the lower the expected risk-taking. In contrast, according to the dummy variables which sought to capture the firm's life cycle, the more advanced the firm's stage is, the lower the absolute value of the coefficient. That is, the smaller would be the negative impact on risk-taking.

To test the robustness of the multiple regression model, we decided to create a paired sample of firms, that is, a sample composed of similar companies, but which differ in the classification between family and unfamiliar firms. The objective is to verify in isolation the effect of the family business on the risk taken by corporations.

To perform the sample matching, we estimated the propensity score matching, which aims to create a control group as similar as possible to the treatment group - but which differ in the presence of the business family. Then, based on the paired sample of firms, it is possible to estimate the average treatment effect (ATE). The treatment variable used is the Fam 1 and Fam 2 dummies (which takes a value of one when the company is family-owned according to its criteria, and zero when not adopting). That is, it aims to demonstrate the impact of being a family business (treatment) on risk-taking. Table 6 summarizes the results of the ATE.

Table 6

ATE test

\begin{tabular}{lcccccc}
\hline & Coef & $\begin{array}{c}\text { Robust Std. } \\
\text { Err. }\end{array}$ & $\mathrm{z}$ & $\mathrm{p}>|\mathrm{z}|$ & \multicolumn{2}{c}{$[95 \% \mathrm{CI}]$} \\
\hline Fam1 & 97,83 & 22,38 & $-4,37$ & 0,000 & $-141,70$ & $-53,98$ \\
Fam2 & $-97,05$ & 21,84 & $-4,44$ & 0,000 & $-139,86$ & $-54,25$ \\
\hline
\end{tabular}

Source: Prepared by the authors.

The result of the mean treatment effect (ATE) was negative for Fam 1 and Fam2. The analysis of the coefficient sign shows that the fact that it is a family firm has a negative impact on its risktaking levels, even with the pairing of the sample. That is, we demonstrate that the business family seeks to incur less risk in the management of their companies since the proposed methodology aims to isolate this relationship - family business and risk-taking. In addition to negative, the coefficient is statistically significant at $1 \%$.

Several factors could explain the negative relationship between risk-taking and the presence of the business family. The first is the fact that family firms tend to take risks more efficiently given the alignment of equity between the firm and business family, and as a consequence, would take less risk proportionately than unfamiliar firms. This stance would be adopted to minimize the losses that may be incurred from a negative outcome since the family would share the residual return of decisions (Fama; Jensen, 1983; Chen; Hsu, 2009).

Other factors may motivate this risk-taking profile, such as Family Socio-Emotional Heritage. Maintaining the affective relationship between members of the business family and the firm can restrict decisions that involve risk-taking. This fact would entail avoiding decisions that most expose the FSH to risk, even if it implies higher potential returns (Gomez-Mejía et al., 2007; Cucculelli; Breton-Miller; Miller, 2016). 
BBR

17

414

The business family can also avoid taking risks by aligning equity between the family and the firm. With family financial returns compromised by the firm's performance, business families can make decisions in a way that does not maximize return but seeks to guarantee an acceptable part of it, setting a conservative stance (Pukall; Calabrò, 2014).

\section{FINAL CONSIDERATIONS}

The main objective of this study was to analyze whether family firms are at less risk than non-familiar firms. For this, we elaborated on a literature review conducted on the two primary constructs worked: family firms and risk-taking. The literature we reviewed showed no consensus on the attitude of family firms to take risk. This evidence encouraged the present research to study the subject empirically through a sample of publicly traded companies in Brazil, a country with a large concentrated capital market.

An empirical line of research gives family firms the risk aversion character. Given the concentration of equity of the business family invested in the firm, the firm chooses to prioritize the firm's long-term survival over potential entrepreneurial opportunities that comprise the risk. Also contributing to risk aversion is the preservation of family socio-emotional heritage, which comprises a number of non-economic goals (Laffranchini; Braun, 2014). By contrast, another line of empirical research argues that business families encourage innovative behavior to gain competitive advantage, maximize shareholder return, and ensure firm longevity. To this end, it is inevitable to engage in initiatives that involve risk. The thin line that separates economic and non-economic objectives in family firms is what makes it difficult to predict the risk trends of this type of enterprise (Gómez-Mejía et al., 2007).

The results found by this study are in line with the first group of empirical studies cited, i.e., there is evidence that family firms have a higher risk aversion than unfamiliar firms. Works such as Chen and Hsu (2009), Anderson et al. (2012), Chrisman et al. (2014), Sciascia et al. (2014), and Kellermanns et al. (2008) demonstrated this same phenomenon in other markets and periods. We believe that the Brazilian market, as it has a high shareholding concentration and a large number of family businesses, adds relevant information on the subject.

This research, of course, presents some limitations and suggestions for future research that wishes to delve into the topics discussed here. We indicated research to analyze the heterogeneity among the group of family firms. Since this type of firm has been set up as a group, it would be interesting to understand how this type of firm differs from each other. For example, it would be interesting to understand which family generation is making firm decisions as well as whether the time that members of the family of business perform in the firm influence the type of choice they make. With the increasing evolution of information provided by firms listed on the Brazilian stock exchange, it is interesting that research uses available knowledge to generate relevant insights for agents dealing with publicly traded firms. We also suggest the elaboration of a continuous variable that expresses the intensity of the family presence, and not a dichotomous variable like the one used here. In addition to this, the combination of the risk-taking construct with other characteristics of firms that may influence their behavior, such as governance levels, is also encouraged. The two constructs worked here are quite large and allow much to be researched. 


\section{REFERENCES}

Allais, M. (1953). Le comportement de l'homme rationnel devant le risque: critique des postulats

et axiomes del' ecole am' ericaine. Econometrica: Journal of the Econometric Society, 21(4), 503-546.

Amihud, Y.; Lev, B. (1981). Risk reduction as a managerial motive for conglomerate mergers. The bell journal of economics, 12(2), 605-617.

Anderson, R. C.; Duru, A.; Reeb, D. M. (2012). Investment policy in family controlled firms. Journal Of Banking \& Finance, 36(6), 1744-1758.

Anderson, R. C.; Reeb, D. M. (2003) Founding-family ownership and firm performance: evidence from the s\&p 500. The Journal Of Finance, 58(3), 1301-1328.

Arrow, K. J. (1952) The principle of rationality in collective decisions. Economie Appliquee, 5, 469-484.

Atkinson, J. W. (1957) Motivational determinants of risk-taking behavior. Psychological Review, 64(6), 359.

Avrichir, I.; Meneses, R.; Santos, A. A. dos. (2016) Do family-managed and non-family-managed firms internationalize differently? Journal of Family Business Management, 6(3), 330-349.

Belkhir, M., \& Chazi, A. (2010). Compensation vega, deregulation, and risk-taking: Lessons from the US banking industry. Journal of Business Finance \& Accounting, 37(9-10), 1218-1247.

Belmonte, V. A. B. \& de Souza Freitas, W. R. (2013). Empresas familiares e a profissionalização da gestão: estudo de casos em empresas paulistas. Revista de Administração da Universidade Federal de Santa Maria, 6(1), 71-89.

Borges, A. F.; Lescura, C.; Oliveira, J. L. de. (2012). O campo de pesquisas sobre empresas familiares no Brasil: análise da produção científica no período 1997-2009. Organizaçóes \& Sociedade, 19(61), 315-332.

Carrasco-Hernandez, A., \& Sánchez-Marín, G. (2007). The determinants of employee compensation in family firms: Empirical evidence. Family business review, 20(3), 215-228.

Cater III, J. J., \& Justis, R. T. (2009). The development of successors from followers to leaders in small family firms: An exploratory study. Family Business Review, 22(2), 109-124.

Casillas, J. C., Moreno, A. M., Barbero, J. L. (2011). Entrepreneurial orientation of family firms: Family and environmental dimensions. Journal of Family Business Strategy, 2(2), 90-100.

Chen, H.-L.; Hsu, W.-T. (2009) Family ownership, board independence, and r\&d investment. Family Business Review, 22(4), 347-362.

Chrisman, J. J.; Chua, J. H.; Steier, L. P. (2003). An introduction to theories of family business. Citeseer, 18, 441-448.

Chrisman, J. J., Memili, E., e Misra, K. (2014). Nonfamily managers, family firms, and the winner's curse: The influence of noneconomic goals and bounded rationality. Entrepreneurship Theory and Practice, 38(5), 1-25.

Coles, J. L., Daniel, N. D., Naveen, L. (2006). Managerial incentives and risk-taking. Journal of Financial Economics, 79(2), 431-468.

Costa, C. M., Galdi, F. C., Motoki, F. Y. (2014) Family management: creating or destroying firm value? Economics Bulletin, 34(4), 2292-2302.

Cucculelli, M., Le Breton-Miller, I., \& Miller, D. (2016). Product innovation, firm renewal and family governance. Journal of Family Business Strategy, 7(2), 90-104. 
BBR

17

416

Davidson, R.; Mackinnon, J. G. (2004). Econometric theory and methods. [S.l.]: Oxford University Press New York, v. 5.

de Vries, M. F. K. (1993). The dynamics of family controlled firms: The good and the bad news. Organizational dynamics, 21(3), 59-71.

Dickinson, V. (2011). Cash flow patterns as a proxy for firm life cycle. The Accounting Review, 86(6), 1969-1994.

Eisenhardt, K. M. (1989). Making fast strategic decisions in high-velocity environments. Academy of Management Journal, 32(3), 543-576.

Faccio, M.; Marchica, M.-T.; Mura, R. (2011). Large shareholder diversification and corporate risktaking. The Review of Financial Studies, 24(11), 3601-3641.

Fama, E. F.; Jensen, M. C. (1983) Separation of ownership and control. The Journal Of Law And Economics, 26(2), 301-325.

Fernandez, Z., \& Nieto, M.J. (2006). Impact of ownership on the international involvement of SMEs. Journal of International Business Studies, 37(3), 340-351.

Gallo, M. A.; Vilaseca, A. (1996). Finance in family business. Family Business Review, 9(4), 387-401.

Goodstein, J., Gautam, K., \& Boeker, W. (1994). The effects of board size and diversity on strategic change. Strategic management journal, 15(3), 241-250.

Gómez-Mejía, L. R. et al. (2007). Socioemotional wealth and business risks in family-controlled firms: Evidence from spanish olive oil mills. Administrative Science Quarterly, 52(1), 106-137.

Guay, W. R. (1999). The sensitivity of ceo wealth to equity risk: an analysis of the magnitude and determinants. Journal of Financial Economics, 53(1), 43-71.

Handler, W. C. (1989). Methodological issues and considerations in studying family businesses. Family business review, (2), 3, 257-276.

Huybrechts, J.; Voordeckers, W.; Lybaert, N. (2013). Entrepreneurial risk taking of private family firms: The influence of a nonfamily ceo and the moderating effect of ceo tenure. Family Business Review, 26(2), 161-179.

Jayantilal, S.; Jorge, S. F.; Palacios, T. M. B. (2016). Effects of sibling competition on family firm succession: A game theory approach. Journal of Family Business Strategy, 7(4), 260-268.

Jensen, M. C.; Meckling, W. H. (1976). Theory of the firm: Managerial behavior, agency costs and ownership structure. Journal of financial economics, 3(4), 305-360.

John, K.; Litov, L.; Yeung, B. (2008). Corporate governance and risk-taking. The Journal of Finance, 63(4), 1679-1728.

Kammler, E. L., \& Alves, T. W. (2009). Análise da capacidade explicativa do investimento pelo q de Tobin em empresas brasileiras de capital aberto. RAE eletrônica, 8(2). http://dx.doi.org/10.1590/ S1676-56482009000200007

Kellermanns, F. W., Eddleston, K. A., Barnett, T., and Pearson, A. (2008). An exploratory study of family member characteristics and involvement: Effects on entrepreneurial behavior in the family firm. Family Business Review, 21(1), 1-14.

Kuang, Y. F.; Qin, B. (2013). Credit ratings and CEO risk-taking incentives. Contemporary Accounting Research, 30(4), 1524-1559.

Laffranchini, G.; Braun, M. (2014). Slack in family firms: evidence from italy (2006-2010). Journal of Family Business Management, 4(2), 171-193. 
Laruccia, M.; Matias, A. M. J. (2015). Motivação como ferramenta para aumento da produtividade em empresas familiares. REMIPE-Revista de Micro e Pequenas Empresas e Empreendedorismo da Fatec Osasco, 1(2), p. 238-262.

Litz, R. A. (1995). The family business: Toward definitional clarity. Family Business Review, 8(2), $71-81$.

March, J. G.; Shapira, Z. (1987). Managerial perspectives on risk and risk taking. Management science, 33(11), 1404-1418.

Markowitz, H. (1952). Portfolio selection. The Journal Of Finance, 7(1), 77-91.

Martínez-Ferrero, J.; Rodríguez-Ariza, L.; Bermejo-Sánchez, M. (2016). Is family ownership of a firm associated with the control of managerial discretion and corporate decisions? Journal of Family Business Management, 6(1), 23-45.

Memili, E. et al. (2010). The critical path to family firm success through entrepreneurial risk taking and image. Journal of Family Business Strategy, 1(4), 200-209.

Miralles-Marcelo, J. L.; Miralles-Quirós, M. del M.; Lisboa, I. (2014). The impact of family control on firm performance: Evidence from Portugal and Spain. Journal of Family Business Strategy, 5(2), $156-168$.

Naldi, L. et al. (2007). Entrepreneurial orientation, risk taking, and performance in family firms. Family Business Review, 20(1), 33-47.

Perlin, M.; Kirch, G.; Vanci N, D. (2018). Accessing financial reports and corporate events with getdfpdata. Brazilian Review of Finance, 17(3), 85-108. http://dx.doi.org/10.12660/rbfin. v17n3.2019.78654

Poutziouris, P.; Smyrnios, K.; Klein, S. (2008). Handbook of research on family business. [S.1.]: Edward Elgar Publishing.

Pukall, T. J.; Calabrò, A.(2014). The internationalization of family firms: A critical review and integrative model. Family Business Review, 27(2), 103-125.

Revilla, A. J.; Pérez-Luño, A.; Nieto, M. J. (2016). Does family involvement in management reduce the risk of business failure? the moderating role of entrepreneurial orientation. Family Business Review, 29(4), 365-379.

Sciascia, S., Mazzola, P., Kellermanns, F. W. (2014). Family management and profitability in private family-owned firms: introducing generational stage and the socioemotional wealth perspective. Journal of Family Business Strategy, 5(2), 131-137.

Smith, C. W., \& Stulz, R. M. (1985). The determinants of firms' hedging policies. Journal offinancial and quantitative analysis, 20(4), 391-405.

Thaler, R. H., \& Sunstein, C. R. (2009). Nudge: Improving decisions about health, wealth, and happiness. Penguin.

Tres, G., Serra, F., Ferreira, M. P. (2014). O tempo de mandato do ceo e o desempenho das empresas: Um estudo comparativo de empresas familiares e não-familiares brasileiras. Revista Gestão \& Tecnologia, 14(3), 5-3.

Tversky, A., \& Kahneman, D. (1979). Prospect theory: An analysis of decision under risk. Econometrica, 47(2), 263-291.

Sharpe, W. F. (1964). Capital asset prices: A theory of market equilibrium under conditions of risk. The Journal Of Finance, 19(3), 425-442. 
BBR

17

418

Vancin, D. F; Procianoy, J. L. (2016). Os fatores determinantes do pagamento de dividendos: o efeito do obrigatório mínimo legal e contratual nas empresas brasileiras. Revista Brasileira de Finanças, 14(1), 89-123.

Villalonga, B.; Amit, R. (2006). How do family ownership, control and management affect firm value? Journal Of Financial Economics, 80(2), 385-417.

von Neumann, J., \& Morgenstern, O. (2007). Theory of games and economic behavior (commemorative edition). Princeton University Press.

Zahra, S. A. (2005). Entrepreneurial risk taking in family firms. Family Business Review, 18(1), 23-40.

Zahra, S. A.; Hayton, J. C.; Salvato, C. (2004). Entrepreneurship in family vs. non-family firms: A resource-based analysis of the effect of organizational culture. Entrepreneurship theory and Practice, 28(4), 363-381.

Zellweger, T. (2007). Time horizon, costs of equity capital, and generic investment strategies of firms. Family Business Review, 20(1), 1-15.

Zyphur, M. J., Narayanan, J., Arvey, R. D., Alexander, G. J. (2009). The genetics of economic risk preferences. Journal of Behavioral Decision Making, 22(4), 367-377. 